\title{
Architectural heritage in the city of Hebron and the rehabilitation of the historical centre
}

\author{
G. J. Dweik \\ Palestine Polytechnic University (PPU), Palestine
}

\begin{abstract}
The entire Arab region is rich in history. Many civilizations lived in the area before and during the Islamic rule, the investigation laid to many evident signs of the past. The main objective of this paper is to highlight the cultural and urban heritage of the old city of Hebron in Palestine. It will also reveal the historical details, the rehabilitation works and also providing the essential needs and services for the area. Souq al wakala in the old city of Hebron has a unique Architecture, the style of this souq (market) is widespread throughout the whole region, testifying to the richness of its history. However, this site has its own characteristics that depend on its history and culture. This site also has its own special historical value, especially in Palestine, that is why "Hebron Rehabilitation Centre" (HRC), focused on rehabilitating and planning to reuse the building as a guest house to cover the HRC, needs to have a rest place for their guests. This paper focuses on restudying the Souq Al-wakala project, which contains many focal functions, such as; restaurant, cafeteria, entrance hall, lecture hall, bedrooms and other building utilities. The purpose of this paper is to prepare designs according to the international standards and requirements regarding the rehabilitation projects so that HRC can benefit.
\end{abstract}

\section{Introduction}

Hebron city is located in the heart of southern part of the west Bank in Palestine, $35 \mathrm{kms}$. South of Jerusalem. It is the biggest city and second oldest city in the west Bank, for this reason, It is home to an estimated 250,000 Palestinians [1] and over 500 Jewish settlers concentrated in and around the old quarter [2]. The city is most notable for containing the traditional burial site of the holy Patriarchs and Matriarchs and is therefore considered the second-holiest city in Judaism after 
Jerusalem [3]. Hebron city is also valued by Muslims for its association with Abraham [4] and was traditionally viewed as one of the "four holy cities of Islam".

It is important to mention that the old centre of Hebron is located in the southeastern part of the new city. Figure 1 shows that the layout of the old city centre was designed to face war, and the unusual walls of the old city were formed by joining the houses to the exterior walls of the outermost houses.

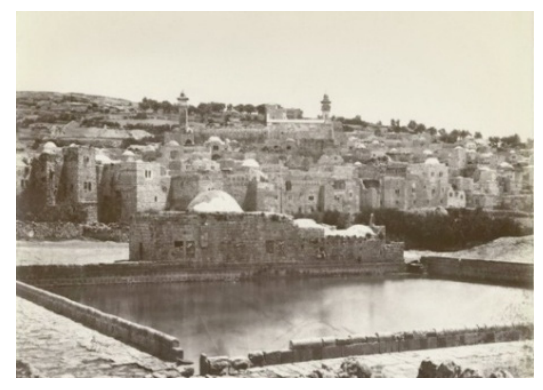

Hebron 1870 A.A.A.S

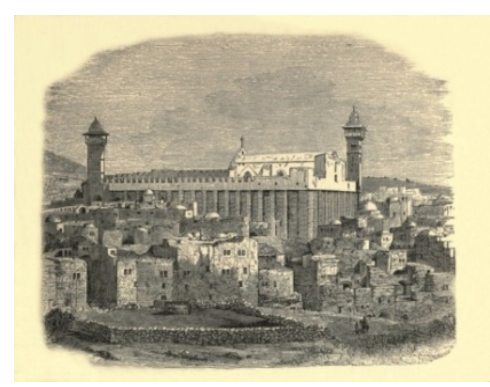

Hebron 1841 A.A.A.S

Figure 1: Layout of the old city before and after the war.

The whole city appears as one big building as heights of individual constructions are approximately the same; only the mosque's minarets reach into the sky, making it very difficult to see the quarters of the city from above. The main market street goes through these big buildings and it is the principal axis of the city. Downtown streets giving access to the residential building were labyrinthine.

Moreover, the appearance of roofs indicates the buildings' structures and the size of the streets was human in scale, although this feature was lost by widening after the introduction of cars.

\section{Chronological growth of the city}

The old city of Hebron faced two main problems. First, there was no vacant enough space, second, the rapid population growth. These two problems forced the city to expand beyond the city walls.

Settlements that have been built outside the city needed protection, so the buildings have been built as compounds.

Near the end of nineteenth century, Al Shallalah and Bab Al Zauieh compounds were built on the main road, on the route towards the north-west. The expansion and business of the city grow more when the cars and buses have been used in the area.

It is important to mention that the expansion first took place around the main entrances to the city; Commercial building were constructed outside the principal entrances of the north, these structure often were attached to the city wall, end screening it from view from the north. Expansion then continued along the historic 
routes from Hebron, principally the northward-bound road leading to Jerusalem and eventually to the Mediterranean ports, and also the westward-bound one leading to Beersheba and to Gaza port.

After the world war one, the British occupation brought modern town planning to the area, they initiated a series of measures aimed to organize and protect the heritage and control development. Through the British initiative, several architects and city planners were brought to Palestine to draw up plans, develop guidelines and design building, not only in Hebron but in cities and village throughout Palestine.

By the late of 1930 s, the north-east and north-west Hebron's sectors were also well established. The area centred around Bab Al Zauieh and Ein Sarah Street was given impetus by the construction of shops which served to expand that zone commercially.

\section{The purpose of the study}

The purpose of this paper is preparing designs according to the international standards and requirements regarding the rehabilitation projects so as (H.R.C) can benefit from.

\subsection{Objectives}

The main aim of this paper is to reverse the process whereby the old city becomes a slum and/or is gradually demolished and built over without respect for its architectural heritage.

The project has undertaken to:

1. Survey and document the old city to establish the present condition of its building and its inhabitants.

2. Draw up plans for the renovation of the building of the old city in accordance with their historical Islamic architectural style.

3. Draw up plans for the renewal of the economic, social and cultural life of the city, so that it may once again be a vibrant city center.

4. Implement selected small pilot conservation.

\subsection{The first stage: surveying and documentation}

Souq Al wakala building is considered one of the Waqf buildings, a gifted building to profit Ibrahim mosque. It was used to receive the visitors of merchants from the surrounding village to spend the season of commerce so they sell their goods in the ground floor and sleep in the first floor of the building.

Souq Al wakala was built on several phases the first was between 550 and 600 Hijri during the crusaders invasion of Hebron. The ground floor was built during this phase. It consists of the main entrance in addition to several spaces surrounding an internal court these spaces were used as shop sell several goods.

The second phase was built during the Ottoman rule. Between 1130 and 1150 Hijri during the rule of Rajab Basha [5], the ruler of Sham district who ordered to 
build a mosque over the existing building on the western side and add more rooms on the northern, southern and eastern sides.

Later, the building was used as commercial and residential space.

New spaces were also added using concrete blocks to meet the new needs.

Nowadays, the building is abundant except some rooms like the pray room and ablution room in the first floor and 3 shops on the ground floor that are used to sell traditional goods.

As shown in Figure 2, the project aims to protect the cultural and urban heritage of the old Hebron city, reveal its historical details, rehabilitate and also providing the essential needs and services for the area.

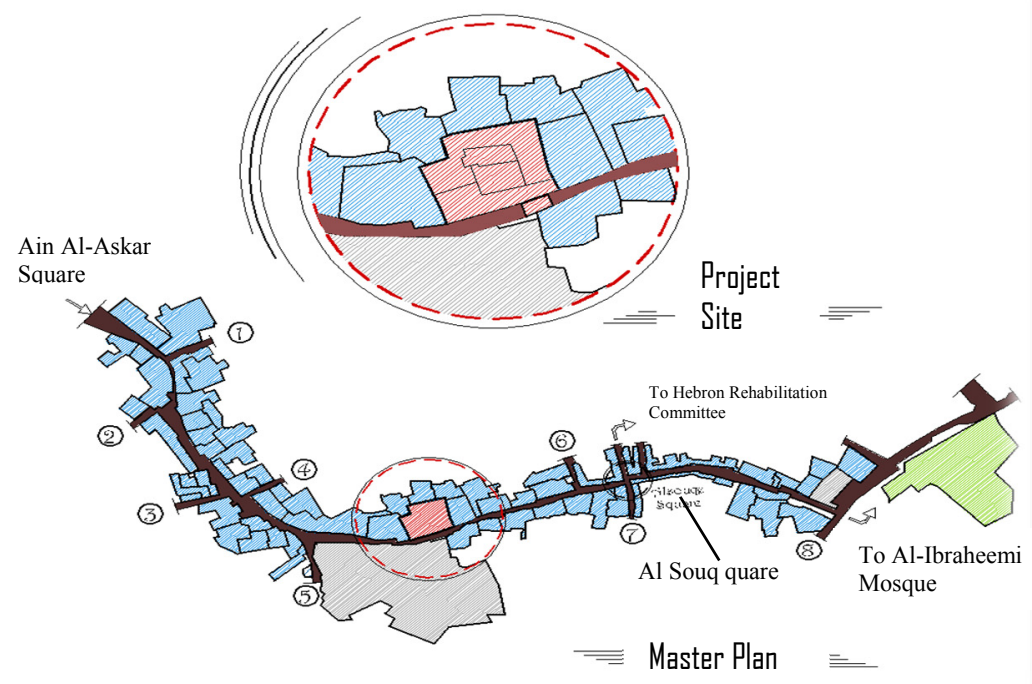

Figure 2: The cultural and urban heritage of the old Hebron city.

\subsection{The goals of the projects}

1- The major goal:

- The main goal is to converse the cultural heritage of the old city of Hebron and to foster its main landmarks historical archeological buildings. Moreover, it aims to rehabilitate these buildings and to provide essential services for the development of the area.

2- The minor goals:

- Job creation.

- Creating an infrastructure for tourism.

- Encourage the projects that serve the old city. 


\section{Research problems}

1. The existence of colonial nodes on the surrounding roofs.

2. The lack of accessibility to the project location due to the closure of the main street that leads to the project by the Israeli military.

3. The existing of abundant historical buildings attached to the project negatively.

4. The difficulty of reopening of several shops since their owners have moved away 15 years ago and their current location is unknown.

5. The existence of a metallic mesh that covers the Qasaba Street and that blocks the façade of the building preventing taking a photo of the façade.

6. Inconvenience because of the residents and pedestrians.

As shown in Figure 3, the building was abandoned for several years, it was full of dogs, insects in addition to dead animals and bad odours.
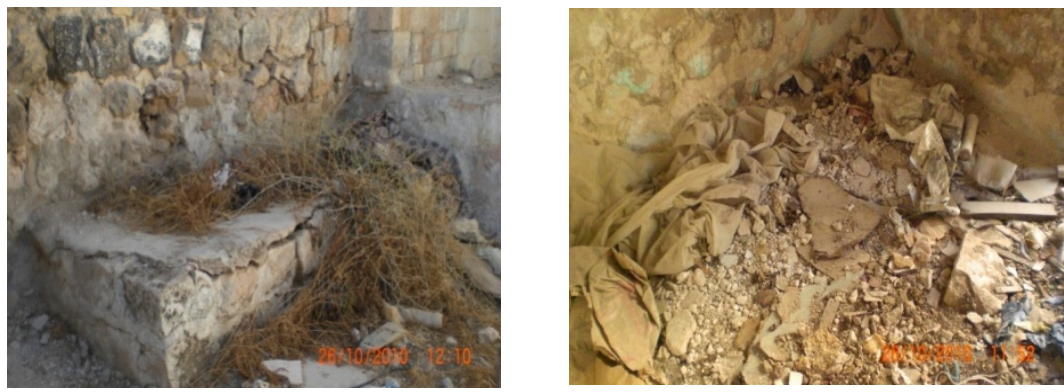

Figure 3: The abandoned building in the old Hebron city.

\section{Steps of surveying}

1. Several exploring visits were made for the building to come up with detailed photos for all the internal and external parts.

2. Accurate measurement of the building had been made in order to draw architectural plans and section in addition to drawing the main elevation and several architectural details of doors, windows and detailed section of the covering materials.

3. Studying the development of the building through the different historical phases and understanding the changes that had taken place on the form of the building.

4. Studying the surrounding area on architectural and social levels.

\section{The composition of the building}

As shown in Figure 4, the building in the old city of Hebron consists of an open court surrounded by spaces of 2 floor height. the ground floor include 12 shops, 
the merchants used for selling their goods six of these stores open to the court and the other 6 opens on the Qasaba street directly .

The first floor was used as a hostel (sleeping area) for the merchants coming from outside the city. It was then converted into offices related to the shops on the ground floor level. This floor was divided into three parts; each has its own court surrounded by attached rooms.

The first part consists of six rooms and a bathroom distribution on a corridor. The second part consists of a central court surrounded by four rooms; three of them to the south and last one to the north. A bathroom is also added to this part using concrete blocks. The $3^{\text {rd }}$ part consist of six bedrooms arranged around a central court that is opened to the main court in addition two toilets were added recently using concrete blocks. Moreover, ablution room and a praying room that is in use until now.

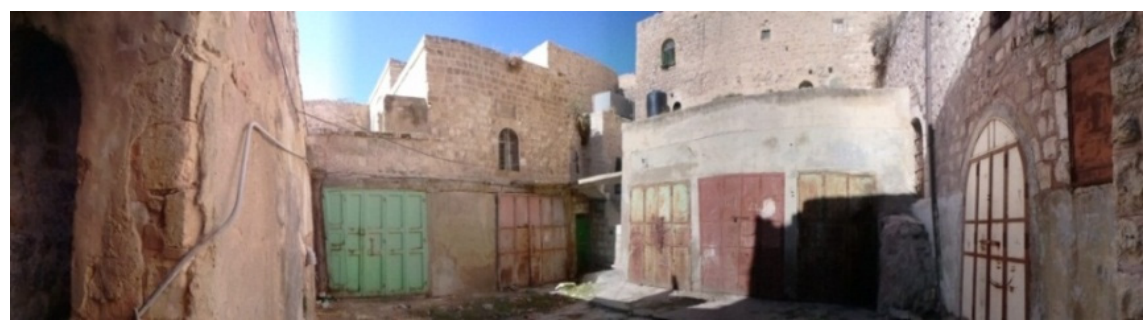

Figure 4: An old building in the old city of Hebron.

The building façade suffers from several problems:

1. The cracked and the drop of kohla.

2. The growing of the grass and putrefaction.

3. The use of several materials like stone and concrete blocks.

4. Visual disturbance by the pipelines.

5. The corrosion of the metallic features of the building.

\section{Methods of construction}

The methods being used in this building are the system of load-bearing walls, where the weight is transferred from the intersecting Arab vaults to the buttresses of the columns and inside the walls in such a way that all four joints make up one ceiling, a pattern which is repeated throw out the building but with different heights and sizes. Thus the weight is transferred from the walls and the columns to the foundations of the walls which stand on the block of stone visible in the floor of the existing basement. There are no spaces in the walls other than the apertures for the doors, the windows, and the cupboards. The ceilings of these apertures in the form of half circles, or domed, because the arch bears the existing pressure better than any other form, and therefore apertures can be made without any noticeable influence on the walls or the distribution of the load. 


\section{The problems of the building}

As shown in Figure 5, a lot of problems have to be taken into account to maintain it, such as:
a. water system;
b. sewage system;
c. electrical system;
d. broken windows, doors (been made out of wood);
e. the plaster work which has deteriorated and flaked in places;
f. the general cleanliness of the buildings, and the different types of flooring;
g. the pointing (kuhla) on the walls;
h. the steps and the balustrades.
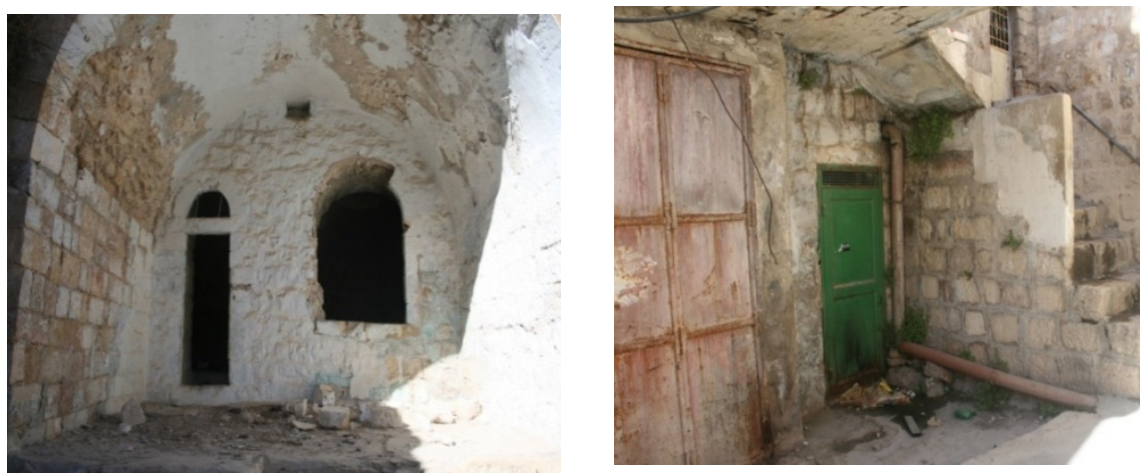

Figure 5: Some clear problems in the chosen building.

\section{New functional drawings to the project steps}

\subsection{Existing ground floor plan}

The ground floor includes 12 shops the merchants used for selling their goods six of these stores open to the court and the other 6 opens on the Qasaba street directly.

\subsection{Existing first floor plan}

The first floor was used as a hostel (sleeping area) for the merchants coming from outside of the city. This floor was divided into three parts, each has its own court surrounded by attached rooms. 


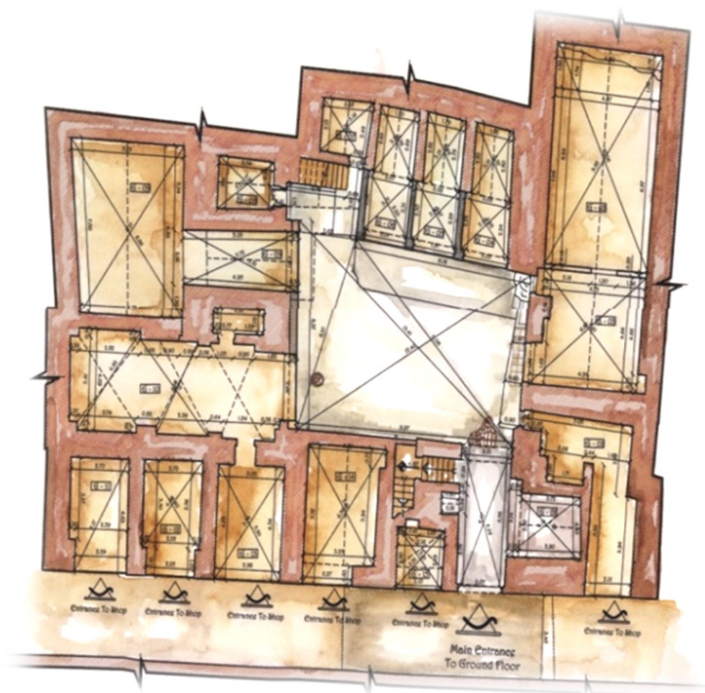

Figure 6: Existing ground floor plan.

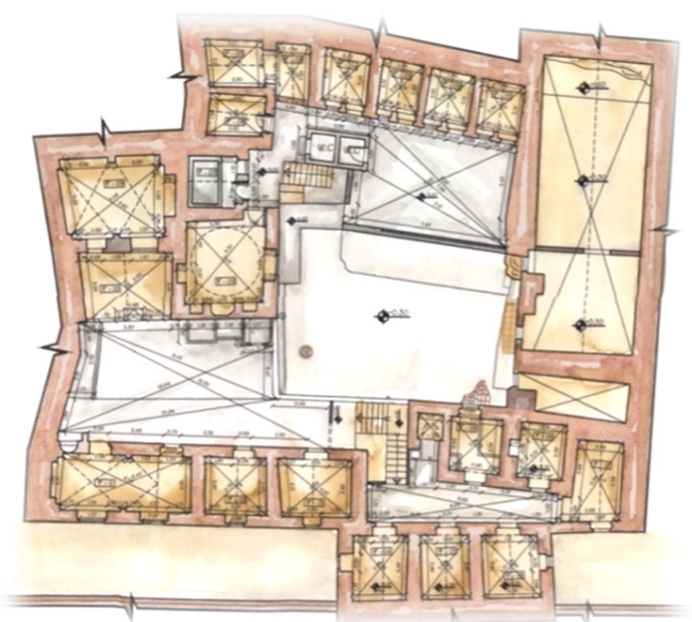

Figure 7: Existing first floor plan.

\subsection{Proposed first floor plan}

As shown in Figure 8, the proposed ground floor include 4 openings on the Qasaba street directly, restaurant, toilets for men and women, coffee shop, lecture hall, manager room, reception and external seats. 


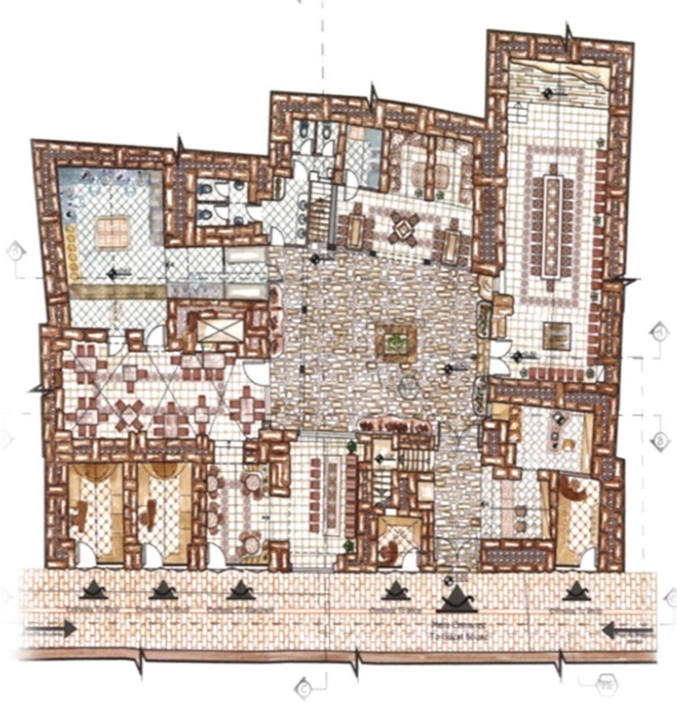

Figure 8: Proposal furniture ground floor plan.

As Figure 9 shows, the proposed furniture first floor include 11 bedroom, toilets for men and women, prayer room, ablution room and external traditional seats.

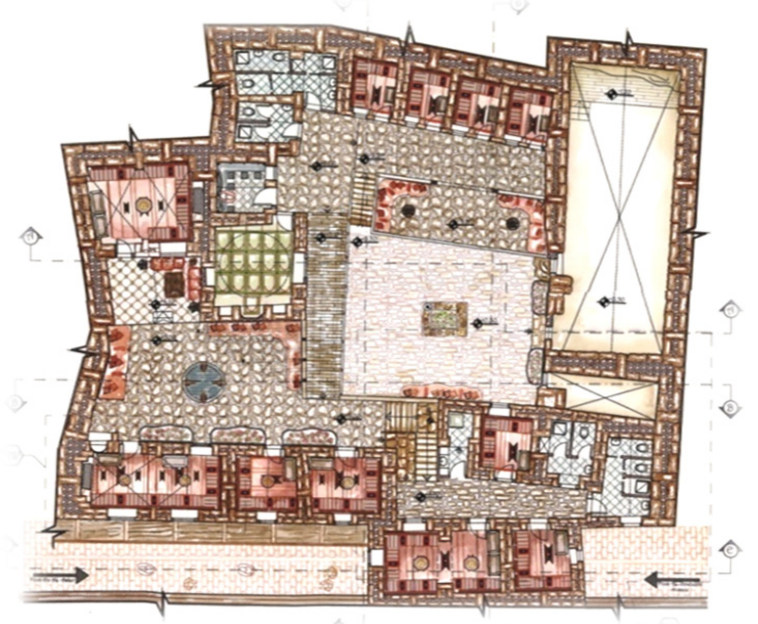

Figure 9: Proposal furniture first floor plan. 
1112 The Sustainable City IX, Vol. 2

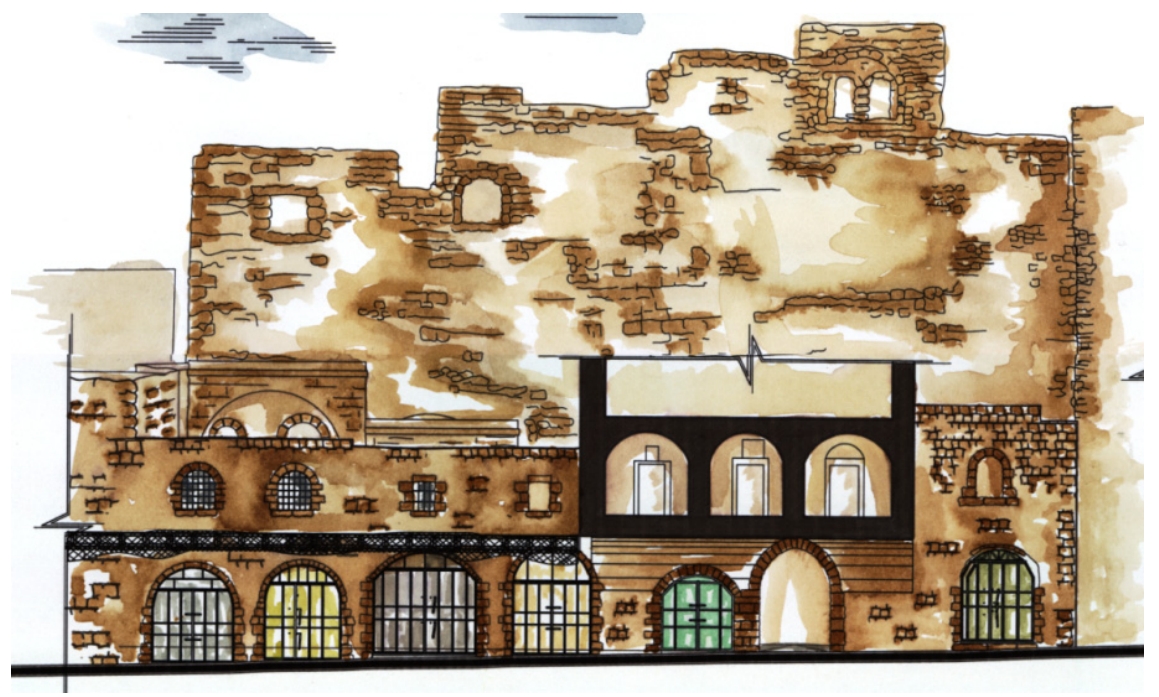

Figure 10: Existing Section E-E.

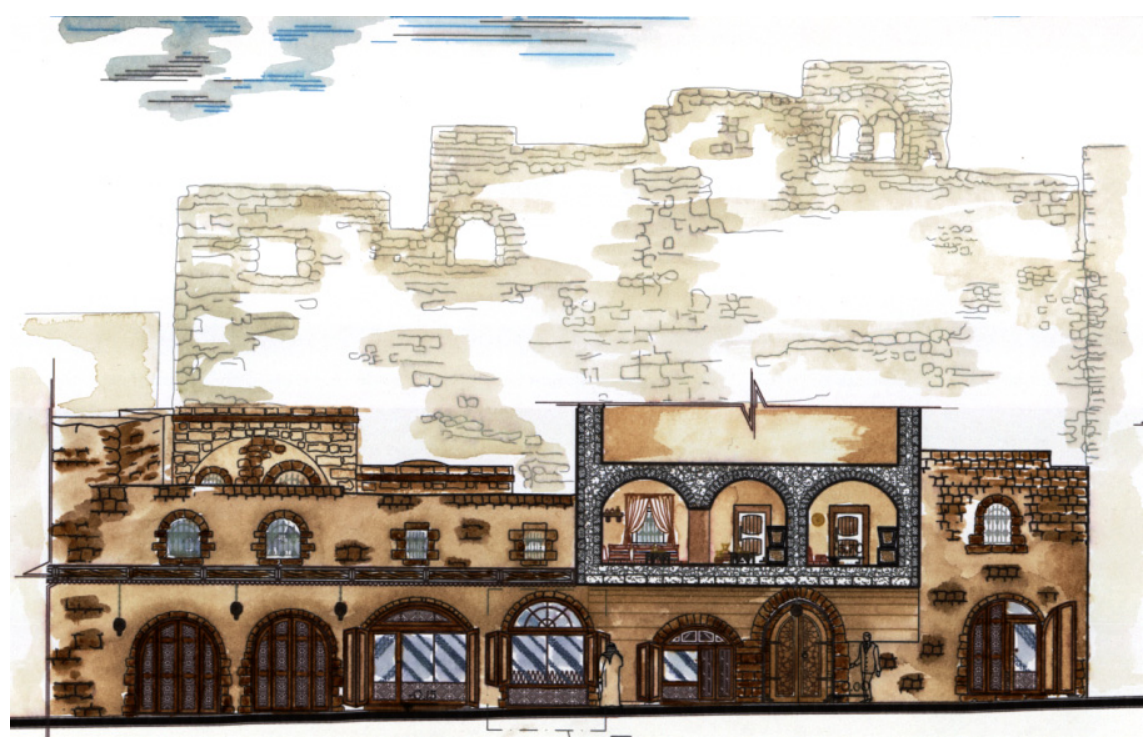

Figure 11: Proposal Furniture Section E-E. 

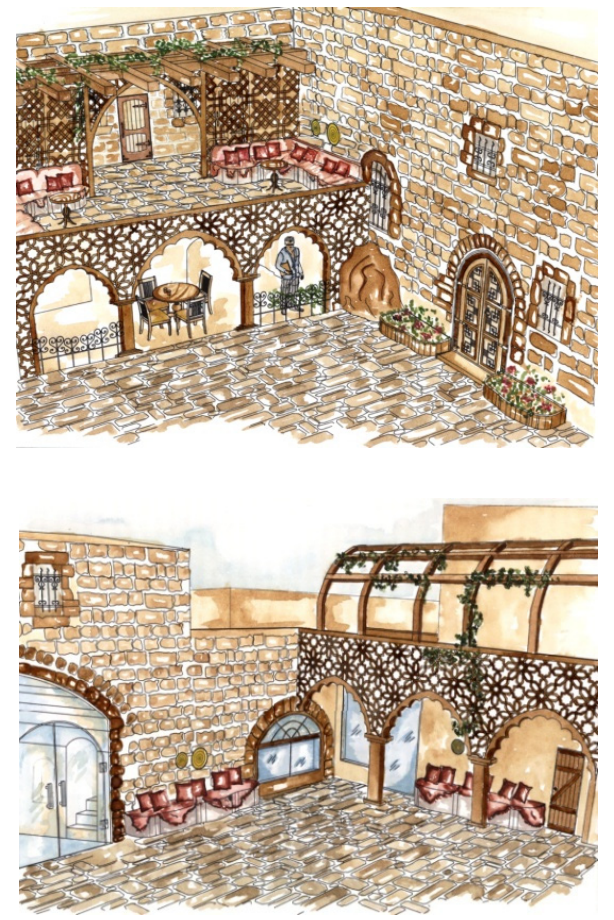

Figure 12: Interior perspectives.

\section{Implementation and estimation of cost}

Studying the architectural plans and the documentation of the building, priorities have now been set the changes which will allow for the required building use. This paper also helped of introducing a new methods of conservation. The security of the building and the safety of the workers during process is paramount. Detailed plans for the implementation of the work with use of support frames, scaffolding and wooden moulds have been drawn up.

Specific plans have been drawn up for the elements of construction and the methods of treatment and conservation. The total cost could reach to $743240 \$$ (US).

\section{References}

[1] Hebron municipality, 2010, http://www.hebron-city.ps/

[2] Sherlock, Ruth, 2010. Palestinian In bid to revive the old city, Hebron residents put on traditional food festival.

[3] Scharfstein, 1994. Understanding Israel, Jerusalem: KTAV Publishing House, Inc. ISBN 978-0-88125-428-0. 
[4] Emmett, Chad F. 2000. Sharing Sacred Space in the Holy Land. In Murphy, Alexander B.; Johnson, Douglas L.; Haarmann, Viola. Cultural encounters with the environment: enduring and evolving geographic themes. Rowman \& Littlefield. pp. 261-282. ISBN 978-0-7425-0106-5. Retrieved 26 May 2011.

[5] Amro, Dr Younis The Arab City of Khalil Al-Rahman, City Has a History 2nd Ed., Hebron University, 1987.

[6] Ashurst, John \& Dimes, Francis G. Stone is Building - Its Use and Potential Today, The Architectural Press, London, 1977.

[7] Baker, David Living in the past, The Historic Environment, Roydon Press, Luton, 1983.

[8] Benvenisti, Meron, The West Bank Data Project. A survey of Israel's Policies American Enterprise Institute for Public Policy Research, Washington and London, 1984.

[9] Feilden, Barnard M. Conservation of Historic Buildings Technical Studies in the Arts, Archaeology, and Architecture, 1982.

[10] Hakim, BasemSalim Arabic - Islamic Cities - Building and Planning Principles, London, 1986.

[11] ICCROM International Meeting of Coordinators of Training in Architectural Conservation, ICCROM, Rome, 1983. 